\title{
Effect of forage brassicas in dairy cow diets on the fatty acid profile and sensory characteristics of Chanco and Ricotta cheeses
}

\author{
Guillermo Seguel, ${ }^{1}$ Juan Pablo Keim, ${ }^{2}$ ๑b Einar Vargas-Bello-Pérez, ${ }^{3,4} \oplus$ Carolina Geldsetzer-Mendoza, ${ }^{4}$ \\ Rodrigo A. Ibáñez, ${ }^{4,5}$ and Christian Alvarado-Gilis ${ }^{2 *}$ (1) \\ ${ }^{1}$ Escuela de Graduados, Facultad de Ciencias Agrarias, Universidad Austral de Chile, Valdivia, Chile 5110566 \\ ${ }^{2}$ Instituto de Producción Animal, Facultad de Ciencias Agrarias, Universidad Austral de Chile, Valdivia, Chile 5110566 \\ ${ }^{3}$ University of Copenhagen, Faculty of Health and Medical Sciences, Department of Veterinary and Animal Sciences, Grønnegårdsvej 3, \\ DK-1870 Frederiksberg C, Denmark \\ ${ }^{4}$ Departamento de Ciencias Animales, Facultad de Agronomía e Ingeniería Forestal, Pontificia Universidad Católica de Chile, \\ C. P. 6904411 Santiago, Chile \\ ${ }^{5}$ Wisconsin Center for Dairy Research, University of Wisconsin-Madison, Madison 53706
}

\section{ABSTRACT}

In humid temperate regions, forage turnip (Brassica rapa ssp. rapa) and forage rape (Brassica napus ssp. biennis) are common fodder crops used for dairy cattle during the summer season. However, there is little scientific information regarding the use of brassicas and their effect on the fatty acid (FA) profile in blood, milk, and milk products. The aim of this study was to evaluate the effect of forage brassica supplementation in dairy cows on the FA profile of blood plasma, milk, and cheese, and on the sensory characteristics of Chanco and Ricotta cheeses. Twelve multiparous dairy cows (Holstein Friesian) were housed and submitted to a $3 \times 3$ replicated $(\mathrm{n}=3)$ Latin square design with 3 treatments (control, turnip, or rape) in 3 periods of 21 $\mathrm{d}$ each (14 d of diet adaptation and $7 \mathrm{~d}$ of measurements). The control diet consisted of $16.20 \mathrm{~kg}$ of grass silage (Lolium perenne), $2.25 \mathrm{~kg}$ of soybean bran, and $2.25 \mathrm{~kg}$ of commercial concentrate, all on a dry matter (DM) basis. In the treatments with forage brassicas, $24.15 \%$ of the total DM was replaced by turnip or rape; thus, they consisted of $12.25 \mathrm{~kg}$ of silage, $2.25 \mathrm{~kg}$ of soybean bran, $1.2 \mathrm{~kg}$ of concentrate, and $5 \mathrm{~kg}$ of turnip or rape (DM basis). A principal components analysis was performed on the results of the cheese sensory evaluation. Supplementation with turnip or rape modified the profile of FA in blood plasma and milk, increasing the saturated fraction, mainly short- and medium-chain FA, and decreasing the mono- and polyunsaturated FA. In the sensory evaluation, diet did not affect any of the 18 attributes evaluated. However, in the principal components analysis, cheeses made with milk from animals

Received June 26, 2019.

Accepted September 21, 2019.

*Corresponding author: calvarado@uach.cl fed turnip and rape were differentiated by increased odor, flavor, spiciness, bitterness, and acidity. Overall, brassicas can be used as an alternative forage source with no negative effects on sensory characteristics of cheeses.

Key words: medium-chain fatty acids, polyunsaturated fatty acids, forage rape, short-chain fatty acids, turnip

\section{INTRODUCTION}

In humid temperate regions (such as Chile, Ireland, and New Zealand), the main feed resources for dairy cattle are permanent pastures, which are characterized by comparatively low production costs that ensure the competitiveness and economical sustainability of the region's dairy farms (Pulido et al., 2010). Milk from pasture systems has a higher content of UFA, including rumenic acid (CLA, C18:2 cis-9,trans-11), compared with milk from cows fed a TMR with a similar dietary lipid content (Schroeder et al., 2003). Thus, pastures have become a valuable tool to increase the concentration of beneficial fatty acids (FA) in milk (Lock and Garnsworthy, 2002) and derived products (McIntosh et al., 2006). However, climatic variation between seasons results in marked differences in pasture production during the year. The nutritional quality decreases in summer as physiological maturity progresses, increasing fiber content and decreasing digestible protein content, which results in a lower DMI (Keim et al., 2015). Therefore, pastures in summer do not satisfy the animals' nutritional requirements and supplementary crops are needed to maintain the profitability of dairy farms (García et al., 2008).

The turnip (Brassica rapa ssp. rapa) and rape (Brassica napus ssp. biennis) are common supplementary crops for cattle feeding during the summer (Barry, 2013). The presence of secondary compounds such as 
glucosinolates, $S$-methylcysteine sulfoxide, and nitrates have been reported in Brassica species. According to Shankaranarayana et al. (1974), glucosinolates belong to the family of sulfur compounds and are associated with a strong and distinct flavor. Wiedenhoeft and Barton (1995) and Moate et al. (1996) noted that glucosinolates can be transferred to the milk, causing an undesired flavor, and can also affect the manufacture of cheeses. Forage brassicas contain high levels of easily fermentable carbohydrates, which improves DM digestibility and ruminal fermentation (Barry, 2013). Sun et al. (2016) showed that supplementation with turnip or rape reduces the acetate-to-propionate ratio and energy losses in the rumen, mainly methane emissions, resulting in improved feed efficiency.

Few studies have reported on the FA profile of brassica-fed dairy cows and their end products. For example, Thomson et al. (2000) found that the shortchain (SCFA) and medium-chain (MCFA) FA in milk increased significantly and UFA decreased when cows were supplemented with turnip compared with cows on a pasture-based diet. However, to the best of our knowledge, no comparison between turnip and rape has been made on fatty acids of milk and organoleptic characteristics of the resultant cheeses. Thus, the aim of this study was to evaluate the effect of supplementation with forage rape or summer turnip in the diet of dairy cows on the FA profile of blood plasma, milk, and cheese, and the organoleptic characteristics of cheeses. In this study, we selected 2 cheese varieties, Chanco and Ricotta. Chanco is one of the main cheese varieties produced in Chile, and it is produced from rennet coagulation of pasteurized milk, with production of lactic acid by mesophilic starter cultures (Vyhmeister et al., 2019). Ricotta cheese is obtained from induced heat-acid coagulation of whey proteins and is generally produced by farmstead cheese producers as an alternative use of sweet whey.

\section{MATERIALS AND METHODS}

\section{Animals and Treatments}

Animal care and procedures were carried out according to the guidelines of the Animal Care Committee of the Universidad Austral de Chile (Valdivia, Chile). Twelve multiparous, mid-lactation $(150 \pm 24 \mathrm{~d})$ dairy cows (Holstein Friesian) were selected based on milk yield $(21.37 \pm 2.45 \mathrm{~L} / \mathrm{d})$. The experiment was carried out in 3 periods of $21 \mathrm{~d}$, which consisted of a 14-d diet adaptation period and a 7-d sampling period, with water offered ad libitum and animals housed in individual stalls.
Table 1 shows the composition of dietary treatments offered. The control diet consisted of $16.20 \mathrm{~kg}$ of grass silage, $2.25 \mathrm{~kg}$ of soybeans, and $2.25 \mathrm{~kg}$ of concentrate, all on a DM basis. In treatments with forage brassicas, $24.15 \%$ of the total DM (20.70 kg of DM/d) was replaced by forage turnip or forage rape, resulting in a diet of $12.25 \mathrm{~kg}$ of silage, $2.25 \mathrm{~kg}$ of soybean meal, 1.20 $\mathrm{kg}$ of concentrate, and $5.00 \mathrm{~kg}$ of forage turnip or forage rape on a DM basis. In addition, $200 \mathrm{~g}$ of mineral salts was offered daily in all of the diets.

\section{DMI, Milk Production, and Milk Composition}

Orts were measured daily to determine daily DMI for each cow. Cows were milked at 0500 and $1500 \mathrm{~h}$, and milk yield was recorded at each milking using automatic milk meters (MM27BC, DeLaval, Tumba, Sweden). The average for the final week of each period is reported. Representative milk samples for a.m. and p.m. milkings $(10 \mathrm{~mL}$ total) were collected on $3 \mathrm{~d}$ in the last week of each the experimental period for fat, protein, lactose, and MUN analyses by infrared spectrophotometer (Foss 4300 Milkoscan, Foss Electric, Hillerød, Denmark).

Table 1. Diet composition of control, turnip, and rape dietary treatments

\begin{tabular}{lrrr}
\hline & \multicolumn{3}{c}{ Diet $^{1}$} \\
\cline { 2 - 4 } Component & Control & Turnip & Rape \\
\hline Ingredient composition (kg of DM/d) & & & \\
Grass silage & 16.20 & 12.25 & 12.25 \\
Soybean bran & 2.25 & 2.25 & 2.25 \\
Concentrate & 2.25 & 1.20 & 1.20 \\
Forage turnip & - & 5.00 & - \\
Forage rape & - & - & 5.00 \\
Chemical composition (\% of DM) & & & \\
DM & 47.34 & 38.23 & 35.94 \\
CP & 19.21 & 20.75 & 21.31 \\
Ether extract & 3.84 & 3.30 & 3.44 \\
NDF & 37.89 & 33.56 & 34.02 \\
ADF & 23.58 & 21.20 & 21.42 \\
Fatty acids & & & \\
C16:0 & 6.5 & 10.31 & 8.87 \\
C18:0 & 2.6 & 3.95 & 20.68 \\
C18:1 & 79.03 & 18.33 & 32.37 \\
C18:2 & 7.38 & 4.23 & 5.87 \\
C18:3 & 3.89 & 15.49 & 20.53 \\
>C20 & 0.59 & 47.7 & 11.68 \\
SFA & 9.11 & 14.26 & 29.55 \\
MUFA & 79.03 & 18.33 & 32.37 \\
PUFA & 11.86 & 67.41 & 38.08 \\
\hline Control & & & \\
\hline
\end{tabular}

${ }^{1}$ Control $=$ no forage brassica supplemented; Turnip $=$ diet supplemented with $5 \mathrm{~kg}$ (DM basis) of forage turnip; Rape = diet supplemented with $5 \mathrm{~kg}$ (DM basis) of forage rape. 


\section{Chemical Analyses of Feeds}

Dry matter content was determined by weighing before and after drying in a forced-air oven at $60^{\circ} \mathrm{C}$ for $48 \mathrm{~h}$ and thereafter at $105^{\circ} \mathrm{C}$ for $12 \mathrm{~h}$. For each feed sample, ash and ether extract were analyzed according AOAC International (1996; methods 942.05 and 920.39, respectively). Nitrogen content was determined by combustion (model FP-428 Nitrogen Determinator, Leco Corp., St Joseph, MI) and used to calculate CP content $(\mathrm{N} \times 6.25) ; \mathrm{NDF}$ was determined according to Van Soest et al. (1991) using heat-stable amylase (Ankom Technology Corp., Macedon, NY) and ADF according to AOAC International (1996; method 973.18). The sequential fiber analysis with correction for residual ash was conducted because pectins and ash can interfere with detergent fiber analysis of brassica forages (Cassida et al., 2007).

\section{Blood Plasma}

In the week of measurement, $10 \mathrm{~mL}$ of blood was obtained from each animal from the coccygeal vein using heparinized vacuum tubes (Becton Dickinson Co., Franklin Lakes, NJ). Each sample was mixed gently and centrifuged at $3,200 \times g$ for $10 \mathrm{~min}$ at room temperature. Plasma was recovered, transferred to plastic vials, and frozen at $-20^{\circ} \mathrm{C}$ for subsequent analysis of FA.

\section{Cheese Making: Chanco and Ricotta}

On the last day of each sampling week, approximately $4 \mathrm{~L}$ of milk was collected from each cow, weighting production in the morning $(60 \% ; 0700 \mathrm{~h})$ and afternoon $(40 \% ; 1630 \mathrm{~h})$ milkings. Later, the milk of the same treatment was mixed and transported at $4^{\circ} \mathrm{C}$ to the Department of Animal Sciences of the Pontificia Universidad Católica de Chile (Santiago, Chile), where the cheeses were made and subjected to sensory analysis.

Chanco cheese manufacturing was carried out based on the protocol described by Vargas-Bello-Pérez et al. (2018) and Oliveira and Brito (2006). The milk obtained from each treatment was pasteurized at $65^{\circ} \mathrm{C}$ for $30 \mathrm{~min}$ and then left to cool to $31^{\circ} \mathrm{C}$. The $\mathrm{pH}$ was then reduced to 5.9 with a $25 \%$ citric acid solution, and $3 \mathrm{~g}$ of calcium chloride was added. After $3 \mathrm{~min}$, $3 \mathrm{~g}$ of commercial rennet powder was added (Nievi, Productos Nievi S.L., Erandio, Spain) and allowed to stand for $45 \mathrm{~min}$. Once the firmness of the curd was evaluated, the curd was cut into cubes of $1 \mathrm{~cm}^{3}$. The curd was gently stirred for $10 \mathrm{~min}$ and then cooked at $38^{\circ} \mathrm{C}$ for $30 \mathrm{~min}$ under constant agitation. The whey was completely drained out of the cheese vats for 30 min. The obtained curd was milled and salted with $0.3 \mathrm{~L}$ of brine solution $(18 \% \mathrm{wt} / \mathrm{vol} \mathrm{NaCl})$ and left to rest for $20 \mathrm{~min}$. The curd was transferred to molds of $250 \mathrm{~g}$ and the cheeses were pressed overnight. Finally, cheeses were transferred to a maturation room where they remained for $21 \mathrm{~d}$ at a temperature of $10^{\circ} \mathrm{C}$ and a relative humidity of $80 \%$.

To make Ricotta cheese, $12 \mathrm{~L}$ of whey was used (obtained during preparation of the Chanco cheese), which was drained and then added to $3 \mathrm{~L}$ of skim milk. The temperature of the whey-milk mixture was increased to $90^{\circ} \mathrm{C}$ and the $\mathrm{pH}$ reduced to 5.4 by adding a citric acid solution ( $25 \% \mathrm{wt} / \mathrm{vol})$. Once the curd began to float on the surface of the cheese pot, it moved slowly from the outside to the center. This process took 10 to $15 \mathrm{~min}$. Subsequently, the curd was maintained at $90^{\circ} \mathrm{C}$ for 10 min before being transferred to $250-\mathrm{g}$ molds. Finally, the Ricotta cheese was left to rest overnight at 2 to $5^{\circ} \mathrm{C}$.

\section{Sensory Analysis of Cheeses}

A descriptive sensory analysis was performed on experimental cheeses. The sensory panel was composed of 14 trained judges who were not provided with any information about the previous treatment of the cheese samples (slices of $1 \mathrm{~cm}^{3}$, approximately $10 \mathrm{~g}$ ). The panelists were given cheese samples in the form of $10 \mathrm{~g}$ slices and evaluated the following attributes: general odor, milk odor, mature cheese odor, general flavor, ripe cheese flavor, astringency, homogeneity, hardness, granularity, sound, spiciness before, spiciness after, bitterness, acid, saltiness, holes, adhesion, and humidity. The judges evaluated the cheeses sequentially by rating the attributes on a continuous intensity scale from 0 to 9 , where 0 means less intense and 9 more intense, according to the description of Vargas-Bello-Pérez et al. (2015). In contrast to Chanco, Ricotta cheeses were informally evaluated by a panel of 5 cheese graders with extensive knowledge and experience to determine main attributes and defects in appearance, texture, flavor, and aromas of milk and dairy products.

\section{Fatty Acid Profile}

Lipids of the samples analyzed (blood plasma, milk, and Chanco and Ricotta cheeses) were extracted according to the method proposed by Bligh and Dyer (1959), and methylation was performed according to the protocol of Christie (1982) with modifications by Chouinard et al. (1999). A gas chromatography system (AOC-20, Shimadzu Scientific Instruments, Columbia, MD) equipped with a 100-m column with the following 
chromatographic conditions was used: after injection, the oven temperature was set at $110^{\circ} \mathrm{C}$ for $4 \mathrm{~min}$ and then raised to $160^{\circ} \mathrm{C}$ at a rate of $5^{\circ} \mathrm{C} / \mathrm{min}$ for $10 \mathrm{~min}$, to $225^{\circ} \mathrm{C}$ at $3^{\circ} \mathrm{C} / \mathrm{min}$ for $10 \mathrm{~min}$, and finally increased to $240^{\circ} \mathrm{C}$ at $3^{\circ} \mathrm{C} / \mathrm{min}$. The temperature of the ionization flame was $260^{\circ} \mathrm{C}$, injection volume $2 \mu \mathrm{L}$, hydrogen flow $25 \mathrm{~mL} / \mathrm{min}$, the air flow $400 \mathrm{~mL} / \mathrm{min}$, and the flow of nitrogen that makes up the gas $40 \mathrm{~mL} / \mathrm{min}$. The fatty acid peaks in the GC were identified using standardization methyl esters of fatty acids (FAME, 37 Component FAME mix, Supelco, Bellefonte, PA).

\section{Nutritional Evaluation of Fat}

The nutritional quality of the FA contained in the milk and cheeses was evaluated as indicated by Ulbricht and Southgate (1991). The atherogenic and thrombogenic indices were determined by the following formulas:

$$
\begin{gathered}
\text { Atherogenic index }=[\mathrm{C} 12: 0+(4 \times \mathrm{C} 14: 0) \\
+ \text { C16:0/(PUFA n- } 6+\text { PUFA n- } 3)+ \text { MUFA }] \text { and } \\
\text { Thrombogenic index }=[(\text { C14:0 }+ \text { C16:0 } \\
+ \text { C18:0/0.5 } \times \text { MUFA })+(0.5 \times \text { PUFA n- } 6) \\
+(3 \times \text { PUFA n- } 3)+(\text { PUFA n-3/PUFA n- } 6)] .
\end{gathered}
$$

When the values of these indices are low, fats are likely to have less negative effects on human health (Allred et al., 2006). Additionally, the n-6/n-3 and PUFA/SFA ratios were determined.

\section{Experimental Design and Statistical Analysis}

According to production, live weight, fat, protein, and DIM, 4 sub-groups of 3 animals (squares) were constituted and randomized to the treatments control, turnip, and rape. The animals went through each of the treatments in a replicated $(\mathrm{n}=4) 3 \times 3$ Latin square design and balanced for residual effects ( 3 treatments and 3 periods of $21 \mathrm{~d}$ ). As a carryover effect was not detected, data were analyzed using the mixed model procedure of SAS (version 9.4, SAS Institute Inc., Cary, $\mathrm{NC)}$ to account for effects of square, period within square, cow within square, and treatment. The dietary treatment was considered a fixed effect; square, period within square, and cow within square were considered random effects.

To determine the FA profile contained in the cheeses (Chanco and Ricotta), a completely randomized block design was used, where the block corresponded to the experimental period.
Before carrying out the ANOVA, the assumptions of normality were checked by the Kolmogorov-Smirnov test and homogeneity of variance with the Levene test. When statistical differences were observed $(P<0.05)$, the means were compared by the Tukey test.

A principal component analysis (PCA) was also carried out on the results of the cheese sensory evaluations by means of the statistical software Minitab 18 (Minitab Inc., State College, PA) to identify groups of data related to the treatments evaluated.

\section{RESULTS AND DISCUSSION}

Under the conditions of this study, forage brassicas were found to be an interesting forage alternative during summer and they can be useful for those farmers seeking added value for their dairy products, including Chanco and Ricotta cheeses. Most of the changes described here are explained by the unique FA profile that brassicas have. In this study, the FA profile from diets (Table 1) showed that brassicas have high contents of FA with $>20$ carbons, which is in agreement with previous research on different brassica species (Sharafi et al., 2015).

\section{Milk Production and Composition}

Milk production and composition did not differ between treatments $(P>0.3$, Table 2$)$. The average milk yield was $24.19 \mathrm{~kg} / \mathrm{d}$, with $4.32 \%$ fat and $3.36 \% \mathrm{CP}$. Differences in DMI, however, were observed $(P<0.01)$ : $19 \mathrm{~kg} / \mathrm{d}$ for control, $17.88 \mathrm{~kg} / \mathrm{d}$ for turnip, and 18.02 $\mathrm{kg} / \mathrm{d}$ for rape treatments. There were no differences between brassicas $(P>0.05)$. The reason for the lower DMI could be the low DM content of diets supplemented with brassicas (Table 1). This effect was previously reported in sheep (Sun et al., 2012) and dairy cattle (Moate et al., 1998), in which the DMI decreased 13 and $16 \%$, respectively, when brassicas were included in diets.

\section{Fatty Acids in Blood Plasma}

Table 3 shows that the concentration of SFA in blood plasma was higher in cows in the turnip and rape treatments, compared with the control $(P<0.01)$. The FA that contributed to this difference were C14:0, C15:0, C16:0, C17:0, and C18:0. The percentage of MUFA was 2.95 and $2.17 \%$ lower in the diet supplemented with forage rape compared with the control and turnip treatments, respectively $(P<0.01)$. Plasma had a lower PUFA content in cows fed forage turnip compared those fed the control and forage rape $\operatorname{diets}(P=0.02)$. 
Table 2. Production and composition of milk from cows fed control, turnip, and rape diets

\begin{tabular}{|c|c|c|c|c|c|}
\hline \multirow[b]{2}{*}{ Parameter } & \multicolumn{3}{|c|}{ Diet $^{1}$} & \multirow[b]{2}{*}{ SEM } & \multirow[b]{2}{*}{$P$-value } \\
\hline & Control & Turnip & Rape & & \\
\hline DMI (kg/d) & $19.00^{\mathrm{a}}$ & $17.88^{\mathrm{b}}$ & $18.02^{\mathrm{b}}$ & 0.46 & $<0.01$ \\
\hline Milk yield $(\mathrm{kg} / \mathrm{d})$ & 24.16 & 24.11 & 24.31 & 0.78 & 0.94 \\
\hline FCM $(\mathrm{kg} / \mathrm{d})$ & 25.19 & 25.17 & 25.76 & 0.90 & 0.66 \\
\hline $\operatorname{ECM}(\mathrm{kg} / \mathrm{d})$ & 26.78 & 26.96 & 27.37 & 0.88 & 0.69 \\
\hline \multicolumn{6}{|l|}{ Composition (\%) } \\
\hline Fat & 4.28 & 4.28 & 4.41 & 0.14 & 0.54 \\
\hline Protein & 3.31 & 3.42 & 3.36 & 0.08 & 0.32 \\
\hline Lactose & 4.87 & 4.84 & 4.88 & 0.03 & 0.40 \\
\hline
\end{tabular}

${ }^{\mathrm{a}, \mathrm{b}}$ Means in the same row with different superscript letters are significantly different $(P<0.05)$.

${ }^{1}$ Control $=$ no forage brassica supplemented; Turnip $=$ diet supplemented with $5 \mathrm{~kg}$ (DM basis) of forage turnip; Rape $=$ diet supplemented with $5 \mathrm{~kg}$ (DM basis) of forage rape.

The total content of n-3 fatty acids was $1.99 \%$ lower in cows supplemented with brassicas $(P<0.01)$ compared with the control group.

At the ruminal level, dietary lipids undergo 2 important modifications: lipolysis and ruminal biohydrogena- tion (RBH). Lipolysis is the process in which lipids are hydrolyzed by lipases (i.e., galactolipases and phospholipases) mostly of bacterial origin and, to a lesser extent, protozoal. This results in the release of FA and glycerol, or, in the case of glycolipids, FA and galactose

Table 3. Fatty acids contained in the blood plasma of cows fed control, turnip, and rape diets

\begin{tabular}{|c|c|c|c|c|c|}
\hline \multirow[b]{2}{*}{ Fatty acid (\%) } & \multicolumn{3}{|c|}{$\operatorname{Diet}^{1}$} & \multirow[b]{2}{*}{ SEM } & \multirow[b]{2}{*}{$P$-value } \\
\hline & Control & Turnip & Rape & & \\
\hline C8:0 & 0.48 & 0.46 & 0.52 & 0.09 & 0.88 \\
\hline C10:0 & 1.59 & 1.30 & 1.93 & 0.30 & 0.34 \\
\hline C14:0 & $0.50^{\mathrm{b}}$ & $0.67^{\mathrm{a}}$ & $0.73^{\mathrm{a}}$ & 0.04 & $<0.01$ \\
\hline C14:1 & $0.31^{\mathrm{a}}$ & $0.21^{\mathrm{b}}$ & $0.21^{\mathrm{b}}$ & 0.03 & 0.04 \\
\hline C15:0 & $0.56^{\mathrm{b}}$ & $0.70^{\mathrm{a}}$ & $0.71^{\mathrm{a}}$ & 0.04 & 0.03 \\
\hline C15:1 & $0.22^{\mathrm{a}}$ & $0.17^{\mathrm{b}}$ & $0.19^{\mathrm{b}}$ & 0.01 & 0.01 \\
\hline $\mathrm{C} 16: 0$ & $15.57^{\mathrm{b}}$ & $17.38^{\mathrm{a}}$ & $18.36^{\mathrm{a}}$ & 0.59 & $<0.01$ \\
\hline $\mathrm{C} 16: 1$ & 0.51 & 0.47 & 0.54 & 0.06 & 0.69 \\
\hline $\mathrm{C} 17: 0$ & $0.87^{\mathrm{b}}$ & $1.04^{\mathrm{ab}}$ & $1.14^{\mathrm{a}}$ & 0.07 & 0.05 \\
\hline $\mathrm{C} 18: 0$ & $22.78^{\mathrm{b}}$ & $26.08^{\mathrm{a}}$ & $24.8^{\mathrm{ab}}$ & 0.67 & 0.01 \\
\hline C18:1 trans -10 & $0.71^{\mathrm{a}}$ & $0.59^{\mathrm{b}}$ & $0.51^{\mathrm{b}}$ & 0.03 & $<0.01$ \\
\hline C18:1 trans-11 & $0.44^{\mathrm{a}}$ & $0.34^{\mathrm{b}}$ & $0.34^{\mathrm{b}}$ & 0.04 & 0.04 \\
\hline $\mathrm{C} 18: 1 \mathrm{n}-9$ cis & $4.91^{\mathrm{a}}$ & $4.47^{\mathrm{a}}$ & $2.34^{\mathrm{b}}$ & 0.44 & $<0.01$ \\
\hline $\mathrm{C} 18: 2 \mathrm{n}-6$ cis & 35.71 & 34.70 & 37.31 & 0.93 & 0.16 \\
\hline C20:0 & 0.38 & 0.38 & 0.36 & 0.05 & 0.92 \\
\hline C18:3n-6 & $0.54^{\mathrm{a}}$ & $0.44^{\mathrm{ab}}$ & $0.30^{\mathrm{b}}$ & 0.05 & $<0.01$ \\
\hline C18:3n-3 & $6.69^{\mathrm{a}}$ & $5.49^{\mathrm{ab}}$ & $5.21^{\mathrm{b}}$ & 0.40 & 0.04 \\
\hline $\mathrm{C} 18: 2$ cis-9,trans- 11 & 0.42 & 0.39 & 0.36 & 0.05 & 0.71 \\
\hline $\mathrm{C} 20: 2$ & 0.19 & 0.13 & 0.13 & 0.03 & 0.22 \\
\hline $\mathrm{C} 22: 0$ & 0.20 & 0.14 & 0.20 & 0.03 & 0.34 \\
\hline$C 20: 3 n-6$ & $1.75^{\mathrm{a}}$ & $1.35^{\mathrm{ab}}$ & $1.14^{\mathrm{b}}$ & 0.17 & 0.05 \\
\hline $\mathrm{C} 20: 4 n-6$ & $2.85^{\mathrm{a}}$ & $1.80^{\mathrm{b}}$ & $1.63^{\mathrm{b}}$ & 0.22 & $<0.01$ \\
\hline $\mathrm{C} 22: 2$ & 0.12 & 0.10 & 0.10 & 0.02 & 0.49 \\
\hline $\mathrm{C} 24: 0$ & 0.14 & 0.11 & 0.11 & 0.02 & 0.33 \\
\hline C20:5n-3 & $0.92^{\mathrm{a}}$ & $0.64^{\mathrm{b}}$ & $0.49^{\mathrm{b}}$ & 0.08 & $<0.01$ \\
\hline C22:6n-3 & $0.71^{\mathrm{a}}$ & $0.41^{\mathrm{b}}$ & $0.38^{\mathrm{b}}$ & 0.05 & $<0.01$ \\
\hline$\Sigma$ SFA & $43.08^{\mathrm{b}}$ & $48.28^{\mathrm{a}}$ & $48.83^{\mathrm{a}}$ & 1.15 & $<0.01$ \\
\hline$\Sigma$ MUFA & $7.08^{\mathrm{a}}$ & $6.30^{\mathrm{a}}$ & $4.13^{\mathrm{b}}$ & 0.44 & $<0.01$ \\
\hline$\Sigma$ PUFA & $49.89^{\mathrm{a}}$ & $45.44^{\mathrm{b}}$ & $47.04^{\mathrm{a}}$ & 1.03 & 0.02 \\
\hline$\Sigma \mathrm{n}-3$ & $8.30^{\mathrm{a}}$ & $6.54^{\mathrm{b}}$ & $6.07^{\mathrm{b}}$ & 0.45 & $<0.01$ \\
\hline$\Sigma \mathrm{n}-6$ & 40.85 & 38.28 & 40.38 & 0.89 & 0.11 \\
\hline
\end{tabular}

${ }^{\mathrm{a}, \mathrm{b}}$ Means in the same row with different superscript letters are significantly different $(P<0.05)$.

${ }^{1}$ Control = no forage brassica supplemented; Turnip = diet supplemented with $5 \mathrm{~kg}$ (DM basis) of forage turnip; Rape $=$ diet supplemented with $5 \mathrm{~kg}$ (DM basis) of forage rape. 
(Lourenço et al., 2010). Ruminal biohydrogenation is a detoxification mechanism that ruminal microorganisms use to protect themselves from the harmful effects of lipids, principally the bactericidal action of free FA. Molecules that have one or more double bonds have a greater antimicrobial power than SFA (Maia et al., 2007). Therefore, the rate of lipolysis and RBH depends on the type of fat in the diet. Consequently, if the content of UFA from food exceeds the detoxification capacity of ruminal microorganisms, both processes lose efficiency, increasing the amount of FA with double bonds that escape from the rumen (Shingfield et al., 2008).

The more important source of FA contained in the blood plasma is the diet, whereas the rest of the FA can be mobilized from the adipose tissue, especially during the first month of lactation (Halmemies-BeauchetFilleau et al., 2013). Thomson et al. (2000) showed that the fatty acids contained in the turnip plant differ from those of forage grasses, mainly because the forage turnip has a greater amount of SFA and lower unsaturated content. However, Khan and Chaudhry (2011) reported that the FA profile of the forage rape plant has less linoleic acid (C18:2n-6 cis) and linolenic acid (C18:3n $-3)$ than that of grass silage.

As mentioned above, a higher concentration of UFA, as shown in the plasma of cows fed the control diet, can be toxic to fiber-fermenting microorganisms, decreasing their efficiency. In this context, Maia et al. (2010) reported a decrease in cellulolytic bacteria due to the increased concentration of UFA in the rumen. Thus, decreasing the fermentation of the fiber results in the simultaneous decrease of acetate production. Since acetate is the main precursor of de novo synthesis in the mammary gland, the SCFA and MCFA content in milk may also decrease. However, Chilliard et al. (2000) indicate that long-chain (LCFA) and very long chain (VLCFA) FA are powerful inhibitors of acetyl-CoA carboxylase, an enzyme used in de novo synthesis of FA.

Numerous studies have shown an increase in the C18:2 cis-9,trans-11 and trans vaccenic acid (TVA, C18:1 trans-11) content of milk when cows are fed diets rich in UFA (Prieto et al., 2016).

\section{Fatty Acids in Milk}

Table 4 shows that the concentration of total SFA increased $4.11 \%$ in the milk of cows fed turnip and rape compared with milk from cows in the control group $(P<0.01)$. The most abundant SFA were $\mathrm{C} 4: 0$, C6:0, C8:0, C10:0, and C16:0. The concentrations of MUFA and PUFA decreased in the treatments supple- mented with brassicas $(P<0.01$ and $P=0.04)$. The least abundant MUFA were C18:1n-9 cis and C20:1n -9 , whereas the least abundant PUFA were C18:2n-6 cis, C18:2 cis-9,trans-11, C18:3n-3, and C22:6n-3. The concentration of n-3 FA, mainly C18:3n-3 and C22:6n -3 , decreased $0.28 \%$ with the supplementation of brassicas $(P<0.01)$.

Nutritional evaluation of FA showed that supplementation with brassicas increased the $\mathrm{n}-6 / \mathrm{n}-3$ ratio $(P<$ 0.01, control: 1.96, turnip: 4.45 and rape: 5.32). Additionally, the PUFA/SFA ratio decreased $(P=0.02$, control: 0.03 , turnip or rape: 0.02). The atherogenic and thrombogenic indices increased (which is less favorable for human health) with the inclusion of brassicas in the diet $(P=0.01$ and $P<0.01$, respectively).

Feeding brassicas resulted in milk with higher percentages of SCFA and MCFA $(P<0.01$ and $P=0.01$, respectively); the main $\mathrm{FA}$ involved were $\mathrm{C} 4: 0, \mathrm{C} 6: 0$, C8:0, and C10:0. However, LCFA were 1.25\% lower, on average, in milk from cows fed the turnip and rape diets compared with the control $(P<0.01)$. The main LCFA with reduced content were $\mathrm{C} 18: 1 \mathrm{n}-9$ cis, C18:2n-6 cis, C18:2 cis-9,trans-11, C18:3n-3, and C20:1n-9 (Table 5).

According to Heid and Keenan (2005), the lipids of bovine milk are contained within the fat globules. The FA in the fat globules of bovine milk have 3 main origins (Clegg et al., 2001): FA contained in the lipoproteins circulating in the blood (from the diet and ruminal digestion), the nonesterified fatty acids from body mobilization (bound to albumin), and FA synthesized de novo in the mammary gland.

The SCFA and MCFA are mostly synthesized de novo in the mammary gland, whereas LCFA and VLCFA come from the lipids circulating in the blood and from the fat mobilized from body reserves (HalmemiesBeauchet-Filleau et al., 2013). In this regard, Bauman et al. (2011) noted that acetate is the main carbon source for most FA that are synthesized. Our results agree with those of Thomson et al. (2000), who found that by supplementing the diet of cows with turnip in the summer period, the concentrations of SCFA and MCFA increased, whereas the amount of UFA decreased compared with a pasture-only diet.

The risk of coronary heart disease associated with SFA varies from no association to a significant risk (Houston, 2018). Also, saturated fats have been shown to have beneficial effects on human health, an aspect that is currently being investigated (O'Sullivan et al., 2013). In the current study, the concentrations of SFA in milk increased when feeding the turnip and rape diets, generally due to differences in the SFA derived from de novo synthesis, such as C4:0, C6:0, C8:0, C10:0, and C16:0, which explains greater synthesis with the 
turnip and rape diets. In addition, the UFA (MUFA and PUFA) decreased, reflecting characteristics of the foods used in the ration. Chilliard et al. (2000) note that PUFA are not synthesized by tissues of ruminants; therefore, their concentration in milk or derived products depends first on the PUFA contained in the diet and then on the amount of PUFA that escapes RBH.
Thomson et al. (2000) reported lower amounts of UFA in milk, including CLA C18:2 cis-9,trans-11, when supplementing the diet of dairy cows with forage turnip.

In the mammary gland, the activity of $\Delta^{9}$-desaturase plays an important role in the degree of desaturation of FA, especially those of 18 carbons (Chilliard et al., 2001). The most relevant desaturation is that of

Table 4. Fatty acids contained in the milk of cows fed control, turnip and rape diets

\begin{tabular}{|c|c|c|c|c|c|}
\hline \multirow[b]{2}{*}{ Fatty acid (\%) } & \multicolumn{3}{|c|}{ Diet $^{1}$} & \multirow[b]{2}{*}{ SEM } & \multirow[b]{2}{*}{$P$-value } \\
\hline & Control & Turnip & Rape & & \\
\hline $\mathrm{C} 4: 0$ & $3.23^{\mathrm{b}}$ & $3.60^{\mathrm{a}}$ & $3.57^{\mathrm{a}}$ & 0.11 & $<0.01$ \\
\hline C6:0 & $2.06^{\mathrm{b}}$ & $2.24^{\mathrm{a}}$ & $2.32^{\mathrm{a}}$ & 0.07 & $<0.01$ \\
\hline C8:0 & $1.12^{\mathrm{b}}$ & $1.23^{\mathrm{a}}$ & $1.29^{\mathrm{a}}$ & 0.05 & $<0.01$ \\
\hline $\mathrm{C} 10: 0$ & $2.74^{\mathrm{b}}$ & $3.03^{\mathrm{ab}}$ & $3.16^{\mathrm{a}}$ & 0.14 & 0.01 \\
\hline C11:0 & 0.26 & 0.35 & 0.30 & 0.04 & 0.27 \\
\hline $\mathrm{C} 12: 0$ & 3.11 & 3.58 & 3.43 & 0.15 & 0.06 \\
\hline C13:0 & 0.07 & 0.10 & 0.08 & 0.02 & 0.44 \\
\hline C14:0 & 12.17 & 11.46 & 12.17 & 0.67 & 0.68 \\
\hline $\mathrm{C} 14: 1$ & 0.82 & 0.87 & 0.91 & 0.06 & 0.29 \\
\hline C15:0 & 0.94 & 0.97 & 0.94 & 0.04 & 0.65 \\
\hline C15:1 & 0.12 & 0.14 & 0.14 & 0.01 & 0.17 \\
\hline C16:0 & $37.46^{\mathrm{b}}$ & $40.04^{\mathrm{a}}$ & $39.99^{\mathrm{a}}$ & 0.78 & $<0.01$ \\
\hline C16:1 & 1.16 & 1.15 & 1.15 & 0.12 & 0.99 \\
\hline $\mathrm{C} 17: 0$ & 0.37 & 0.39 & 0.38 & 0.02 & 0.69 \\
\hline $\mathrm{C} 17: 1$ & 0.21 & 0.19 & 0.17 & 0.02 & 0.43 \\
\hline C18:0 & 8.52 & 8.70 & 9.23 & 0.50 & 0.60 \\
\hline C18:1 trans -10 & 0.07 & 0.02 & 0.01 & 0.02 & 0.16 \\
\hline C18:1 trans -11 & 0.28 & 0.05 & 0.03 & 0.09 & 0.09 \\
\hline $\mathrm{C} 18: 1 \mathrm{n}-9$ cis & $22.70^{\mathrm{a}}$ & $20.12^{\mathrm{b}}$ & $18.94^{\mathrm{b}}$ & 0.65 & $<0.01$ \\
\hline C18:2n-6 trans & $0.45^{\mathrm{b}}$ & $0.54^{\mathrm{ab}}$ & $0.62^{\mathrm{a}}$ & 0.05 & 0.03 \\
\hline $\mathrm{C} 18: 2 \mathrm{n}-6$ cis & $0.11^{\mathrm{a}}$ & $0.07^{\mathrm{ab}}$ & $0.05^{\mathrm{b}}$ & 0.01 & 0.02 \\
\hline $\mathrm{C} 20: 0$ & 0.04 & 0.02 & 0.02 & 0.02 & 0.67 \\
\hline C20:1n-9 & $0.05^{\mathrm{a}}$ & $0.01^{\mathrm{ab}}$ & $0.00^{\mathrm{b}}$ & 0.01 & 0.03 \\
\hline C18:3n-6 & 0.05 & 0.01 & 0.02 & 0.01 & 0.16 \\
\hline C18:3n-3 & $0.32^{\mathrm{a}}$ & $0.10^{\mathrm{b}}$ & $0.08^{\mathrm{b}}$ & 0.04 & $<0.01$ \\
\hline C18:2 cis-9,trans-11 & $0.49^{\mathrm{a}}$ & $0.39^{\mathrm{b}}$ & $0.44^{\mathrm{ab}}$ & 0.03 & 0.02 \\
\hline $\mathrm{C} 20: 2$ & 0.09 & 0.05 & 0.02 & 0.04 & 0.18 \\
\hline $\mathrm{C} 22: 0$ & 0.12 & 0.15 & 0.10 & 0.06 & 0.84 \\
\hline $\mathrm{C} 20: 3 \mathrm{n}-3$ & 0.04 & 0.04 & 0.02 & 0.01 & 0.52 \\
\hline $\mathrm{C} 20: 3 \mathrm{n}-6$ & 0.14 & 0.07 & 0.07 & 0.05 & 0.57 \\
\hline C22:1n-9 & 0.09 & 0.05 & 0.07 & 0.05 & 0.81 \\
\hline $\mathrm{C} 23: 0$ & 0.13 & 0.05 & 0.05 & 0.07 & 0.63 \\
\hline C20:4n-6 & 0.07 & 0.03 & 0.04 & 0.02 & 0.48 \\
\hline $\mathrm{C} 22: 2$ & 0.15 & 0.03 & 0.05 & 0.05 & 0.23 \\
\hline $\mathrm{C} 24: 0$ & 0.10 & 0.08 & 0.07 & 0.05 & 0.92 \\
\hline C20:5n-3 & 0.05 & 0.03 & 0.03 & 0.01 & 0.32 \\
\hline $\mathrm{C} 24: 1 \mathrm{n}-9$ & 0.04 & 0.01 & 0.01 & 0.01 & 0.13 \\
\hline $\mathrm{C} 22: 6 \mathrm{n}-3$ & $0.05^{\mathrm{a}}$ & $0.04^{\mathrm{ab}}$ & $0.01^{\mathrm{b}}$ & 0.01 & 0.02 \\
\hline$\Sigma \mathrm{SFA}$ & $72.45^{\mathrm{b}}$ & $75.99^{\mathrm{a}}$ & $77.13^{\mathrm{a}}$ & 0.73 & $<0.01$ \\
\hline$\Sigma$ MUFA & $25.53^{\mathrm{a}}$ & $22.60^{\mathrm{b}}$ & $21.42^{\mathrm{b}}$ & 0.64 & $<0.01$ \\
\hline$\Sigma \mathrm{PUFA}$ & $2.01^{\mathrm{a}}$ & $1.41^{\mathrm{b}}$ & $1.45^{\mathrm{b}}$ & 0.18 & 0.04 \\
\hline$\Sigma \mathrm{n}-3$ & $0.47^{\mathrm{a}}$ & $0.21^{\mathrm{b}}$ & $0.16^{\mathrm{b}}$ & 0.05 & $<0.01$ \\
\hline$\Sigma \mathrm{n}-6$ & 0.81 & 0.73 & 0.80 & 0.08 & 0.65 \\
\hline$\Sigma \mathrm{n}-6 / \Sigma \mathrm{n}-3$ & $1.96^{\mathrm{b}}$ & $4.45^{\mathrm{a}}$ & $5.32^{\mathrm{a}}$ & 0.39 & $<0.01$ \\
\hline$\Sigma \mathrm{PUFA} / \Sigma \mathrm{SFA}$ & $0.03^{\mathrm{a}}$ & $0.02^{\mathrm{b}}$ & $0.02^{\mathrm{b}}$ & 0.01 & 0.02 \\
\hline Atherogenic index & $3.39^{\mathrm{b}}$ & $3.82^{\mathrm{ab}}$ & $4.17^{\mathrm{a}}$ & 0.15 & 0.01 \\
\hline Thrombogenic index & $3.93^{\mathrm{b}}$ & $4.82^{\mathrm{a}}$ & $5.31^{\mathrm{a}}$ & 0.18 & $<0.01$ \\
\hline
\end{tabular}

${ }^{\mathrm{a}, \mathrm{b}}$ Means in the same row with different superscript letters are significantly different $(P<0.05)$.

${ }^{1}$ Control $=$ no forage brassica supplemented; Turnip $=$ diet supplemented with $5 \mathrm{~kg}$ (DM basis) of forage turnip; Rape $=$ diet supplemented with $5 \mathrm{~kg}$ (DM basis) of forage rape. 
Table 5. Fatty acid profile of milk classified according to the number of carbon atoms

\begin{tabular}{lcccrr}
\hline & \multicolumn{5}{c}{ Diet $^{2}$} \\
\cline { 2 - 4 } Fatty acid & & & \\
& Control & Turnip & Rape & SEM & $P$-value \\
\hline SCFA (3-7 C) & $5.29^{\mathrm{b}}$ & $5.84^{\mathrm{a}}$ & $5.90^{\mathrm{a}}$ & 0.17 & $<0.01$ \\
MCFA (8-13 C) & $7.29^{\mathrm{b}}$ & $8.29^{\mathrm{a}}$ & $8.26^{\mathrm{a}}$ & 0.33 & 0.01 \\
LCFA (14-20 C) & $86.73^{\mathrm{a}}$ & $85.47^{\mathrm{b}}$ & $85.48^{\mathrm{b}}$ & 0.45 & $<0.01$ \\
VLCFA (>21 C) & 0.68 & 0.41 & 0.36 & 0.24 & 0.61 \\
\hline a,b Means in the same row with different superscript letters are significantly different $(P<0.05)$. \\
${ }^{1}$ SCFA = short-chain fatty acids; MCFA = medium-chain fatty acids; LCFA = long-chain fatty acids; VLCFA \\
= very long chain fatty acids. \\
${ }^{2}$ Control = no forage brassica supplemented; Turnip = diet supplemented with 5 kg (DM basis) of forage tur- \\
nip; Rape = diet supplemented with 5 kg (DM basis) of forage rape.
\end{tabular}

TVA, which results in the formation of CLA C18:2 cis9,trans-11 (Pariza et al., 2001). The concentration of CLA C18:2 cis-9,trans-11 was higher with the control diet than with the turnip diet. This could be due to the greater amount of TVA present in blood plasma of cows fed the control diet.

Regarding the nutritional evaluation of the milk FA, we observed that the n- $6 / \mathrm{n}-3$ ratio was higher for milk from the turnip and rape treatments. The recommended value for this ratio is $<4$ (British Department of Health, 1994), a recommendation that was met only in control milk. However, the PUFA/SFA ratio in milk from all of the diets was below the recommended amount $(\sim 0.45)$.

Ulbricht and Southgate (1991) define the atherogenic index as the ability of fats to produce a plaque in the endothelium of blood vessels and the thrombogenic index as the ability of fats to produce thrombosis. Therefore, the milk of cows fed the control treatment had better nutritional quality than milk from the treatments supplemented with brassicas, as indicated by the lower n-3/n-6 ratio, atherogenic index, and thrombogenic index.

\section{Fatty Acids in Chanco Cheese}

The percentages of SFA, MUFA, PUFA, and n-6 FA were not affected by treatment $(P>0.05$, Table 6$)$ and neither were the ratios of $\mathrm{n}-6 / \mathrm{n}-3$ and PUFA/SFA $(P$ $>0.05)$. However, concentrations of $\mathrm{C} 14: 0$ and C16:0 were higher in Chanco cheese from cows supplemented with brassicas $(P<0.05)$. Additionally, supplementation with turnip or rape reduced the concentration of n-3 FA by $0.12 \%(P<0.01)$, and the same diets showed higher atherogenic and thrombogenic indices $(P=0.02$ and $P<0.01$, respectively).

The quality and composition of cheese are strongly influenced by factors attributable to the initial milk quality (Lobos-Ortega et al., 2012). Falchero et al. (2010) reported similar values between the FA profile of milk and cheese. Scerra et al. (2016) pointed out that the processing of milk does not, to a great extent, alter the composition of FA contained in the cheeses. Although the cheeses of the control diet had a lower SFA fraction than cheeses of the turnip and rape diets (2.33 and $3.89 \%$ respectively), there were no major statistical differences (as in the FA profile of the milk), perhaps due to the number of replicates. However, the concentration of palmitic acid (C16:0) was higher in both milk and cheeses from cows fed forage brassicas.

\section{Fatty Acids in Ricotta Cheese}

Table 7 shows that the n-3 FA content was lower in Ricotta cheese from the rape treatment $(P<0.01)$. In addition, the atherogenic and thrombogenic indices were higher in cheese from cows supplemented with forage brassicas $(P=0.03$ and $P=0.04$, respectively). However, SFA, MUFA, PUFA, n-6 FA, n-6/n-3 ratio, and PUFA/SFA ratio did not differ between the evaluated diets $(P>0.05)$. The exceptions were the SFA C14:0 and C16:0; the former was higher in the rape diet $(P=0.03)$ and the latter was higher in the turnip and rape diets $(P=0.02)$. In contrast, the concentration of $\mathrm{C} 20: 5 \mathrm{n}-3$ (eicosapentaenoic acid) decreased in the cheese of cows fed brassicas $(P=0.04)$.

The FA profile of Ricotta cheese was similar to that of Chanco cheese, mainly because Ricotta cheese was prepared from whey obtained during the preparation of the Chanco cheese. Similarly, in cows grazing summer highland pastures, Bergamaschi and Bittante (2017) found that milk, fresh cheese, and Ricotta cheese had similar contents of SFA and UFA. Nudda et al. (2005) found that in sheep dairy products, the FA concentrations in fresh cheese and Ricotta cheese depended mainly on the FA content of unprocessed raw milk, in agreement with results of Lobos-Ortega et al. (2012).

Our results indicated that the nutritional quality (atherogenic and thrombogenic indices) of the cheeses 
depended mainly on the nutritional quality of the unprocessed milk. Currently, we are not aware of any other studies related to the use of forages or to the use of diets based on grass silage on the FA profile in Chanco and Ricotta cheeses. Due to the importance of FA in human health, more research is needed in this area.

\section{Sensory Analysis of Chanco and Ricotta Cheeses}

In Chanco cheese, diet did not affect any of the 18 attributes considered: homogeneity, holes, general smell, smell of ripe cheese, smell of milk, salty, sour, bitter, spiciness before swallowing, spiciness after swallowing, general flavor, ripe cheese flavor, astringency, hardness,

Table 6. Fatty acids contained in Chanco cheese from milk of cows fed control, turnip, and rape diets

\begin{tabular}{|c|c|c|c|c|c|}
\hline \multirow[b]{2}{*}{ Fatty acid (\%) } & \multicolumn{3}{|c|}{ Diet $^{1}$} & \multirow[b]{2}{*}{ SEM } & \multirow[b]{2}{*}{$P$-value } \\
\hline & Control & Turnip & Rape & & \\
\hline C4:0 & 3.89 & 3.93 & 4.18 & 0.07 & 0.66 \\
\hline C6:0 & 2.56 & 2.15 & 2.68 & 0.03 & 0.49 \\
\hline C8:0 & 1.29 & 1.35 & 1.43 & 0.04 & 0.86 \\
\hline C10:0 & 2.75 & 2.39 & 3.23 & 0.11 & 0.81 \\
\hline C11:0 & 0.29 & 0.31 & 0.33 & 0.02 & 0.72 \\
\hline C12:0 & 3.21 & 3.73 & 3.67 & 0.14 & 0.87 \\
\hline C13:0 & 0.08 & 0.07 & 0.07 & 0.01 & 1.00 \\
\hline C14:0 & $11.63^{\mathrm{b}}$ & $12.29^{\mathrm{a}}$ & $12.25^{\mathrm{a}}$ & 0.03 & 0.04 \\
\hline C14:1 & 0.81 & 0.96 & 1.02 & 0.07 & 0.93 \\
\hline C15:0 & 0.97 & 0.98 & 0.97 & 0.06 & 0.64 \\
\hline C15:1 & 0.12 & 0.23 & 0.12 & 0.01 & 0.11 \\
\hline C16:0 & $37.12^{\mathrm{b}}$ & $39.01^{\mathrm{a}}$ & $38.43^{\mathrm{a}}$ & 0.49 & 0.01 \\
\hline C16:1 & 1.21 & 1.33 & 1.24 & 0.08 & 0.84 \\
\hline C17:0 & 0.36 & 0.42 & 0.41 & 0.02 & 0.53 \\
\hline $\mathrm{C} 17: 1$ & 0.22 & 0.21 & 0.21 & 0.01 & 0.82 \\
\hline C18:0 & 8.92 & 9.55 & 10.03 & 0.81 & 0.63 \\
\hline C18:1 trans -10 & 0.04 & 0.04 & 0.02 & 0.01 & 0.26 \\
\hline C18:1 trans -11 & 0.06 & 0.08 & 0.03 & 0.01 & 0.11 \\
\hline C18:1n-9 cis & 20.75 & 18.94 & 18.05 & 1.24 & 0.42 \\
\hline $\mathrm{C} 18: 2 \mathrm{n}-6$ trans & 0.74 & 0.70 & 0.67 & 0.01 & 0.70 \\
\hline C18:2n-6 cis & 0.07 & 0.04 & 0.04 & 0.01 & 0.96 \\
\hline C20:0 & 0.01 & 0.05 & 0.08 & 0.03 & 0.41 \\
\hline C20:1n-9 & 0.02 & 0.01 & $\mathrm{ND}^{2}$ & 0.01 & 0.53 \\
\hline C18:3n-6 & 0.01 & 0.01 & ND & 0.01 & 0.69 \\
\hline C18:3n-3 & 0.34 & 0.32 & 0.17 & 0.05 & 0.09 \\
\hline C18:2 cis-9,trans-11 & 0.41 & 0.36 & 0.43 & 0.03 & 0.09 \\
\hline $\mathrm{C} 20: 2$ & 0.01 & 0.02 & 0.01 & 0.01 & 0.76 \\
\hline C22:0 & 0.05 & 0.05 & 0.07 & 0.02 & 0.57 \\
\hline $\mathrm{C} 20: 3 \mathrm{n}-3$ & 0.01 & 0.05 & 0.01 & 0.01 & 0.55 \\
\hline C20:3n-6 & 0.03 & 0.11 & 0.02 & 0.01 & 0.59 \\
\hline C22:1n-9 & 0.05 & 0.11 & 0.02 & 0.01 & 0.50 \\
\hline $\mathrm{C} 23: 0$ & 0.02 & 0.03 & 0.05 & 0.01 & 0.37 \\
\hline C20:4n-6 & 0.05 & 0.12 & 0.01 & 0.01 & 0.05 \\
\hline $\mathrm{C} 22: 2$ & 0.02 & ND & 0.01 & 0.01 & 0.11 \\
\hline C24:0 & 0.02 & 0.02 & 0.01 & 0.01 & 0.61 \\
\hline C20:5n-3 & 0.03 & 0.01 & 0.02 & 0.01 & 0.63 \\
\hline C24:1n-9 & 0.04 & 0.03 & 0.03 & 0.01 & 0.95 \\
\hline C22:6n-3 & 0.01 & 0.01 & 0.01 & 0.01 & 0.26 \\
\hline$\Sigma \mathrm{SFA}$ & 73.99 & 76.32 & 77.88 & 1.30 & 0.11 \\
\hline$\Sigma$ MUFA & 24.28 & 21.93 & 20.73 & 1.18 & 0.22 \\
\hline$\Sigma$ PUFA & 1.73 & 1.75 & 1.39 & 0.57 & 0.17 \\
\hline$\Sigma \mathrm{n}-3$ & $0.40^{\mathrm{a}}$ & $0.36^{\mathrm{b}}$ & $0.21^{\mathrm{b}}$ & 0.04 & $<0.01$ \\
\hline$\Sigma \mathrm{n}-6$ & 0.90 & 0.98 & 0.73 & 0.16 & 0.40 \\
\hline$\Sigma \mathrm{n}-6 / \Sigma \mathrm{n}-3$ & 2.31 & 2.54 & 3.59 & 0.36 & 0.12 \\
\hline$\Sigma$ PUFA/ $\Sigma$ SFA & 0.02 & 0.02 & 0.02 & 0.02 & 0.44 \\
\hline Atherogenic index & $3.50^{\mathrm{b}}$ & $3.94^{\mathrm{a}}$ & $4.32^{\mathrm{a}}$ & 0.18 & 0.02 \\
\hline Thrombogenic index & $4.10^{\mathrm{b}}$ & $4.68^{\mathrm{a}}$ & $5.37^{\mathrm{a}}$ & 0.17 & $<0.01$ \\
\hline
\end{tabular}

$\overline{a, b}$ Means in the same row with different superscript letters are significantly different $(P<0.05)$.

${ }^{1} \mathrm{Control}=$ no forage brassica supplemented; Turnip = diet supplemented with $5 \mathrm{~kg}$ (DM basis) of forage turnip; Rape $=$ diet supplemented with $5 \mathrm{~kg}$ (DM basis) of forage rape.

${ }^{2}$ Not detected. 
granularity, sound, humidity, or adhesion $(P>0.05$, Table 8). However, in the PCA, 2 components were selected. The main component 1 (PC1) explained 59.1\% of the total variability and differentiated the rape cheese from the control and turnip cheeses; the rape cheese showed greater intensity of general flavor, humidity, ripe cheese flavor, salty, smell of mature cheese, general smell, and spiciness after swallowing. The rape cheese was also characterized as a cheese with less hardness, astringency, sound, and granularity. In contrast, main component 2 (PC2) explained $40.9 \%$ of the total variability and differentiated the control cheese from the turnip and rape cheeses; the control cheese had greater homogeneity, whereas the turnip and rape cheeses were

Table 7. Fatty acids contained in Ricotta cheese from milk of cows fed control, turnip and rape diets

\begin{tabular}{|c|c|c|c|c|c|}
\hline \multirow[b]{2}{*}{ Fatty acid (\%) } & \multicolumn{3}{|c|}{ Diet $^{1}$} & \multirow[b]{2}{*}{ SEM } & \multirow[b]{2}{*}{$P$-value } \\
\hline & Control & Turnip & Rape & & \\
\hline $\mathrm{C} 4: 0$ & 3.57 & 4.20 & 3.86 & 0.13 & 0.18 \\
\hline C6:0 & 2.14 & 2.13 & 2.29 & 0.05 & 0.45 \\
\hline C8:0 & 1.18 & 1.20 & 1.30 & 0.03 & 0.38 \\
\hline C10:0 & 2.76 & 2.63 & 3.05 & 0.14 & 0.46 \\
\hline C11:0 & 0.28 & 0.27 & 0.33 & 0.02 & 0.06 \\
\hline C12:0 & 3.21 & 3.43 & 3.53 & 0.11 & 0.42 \\
\hline C13:0 & 0.08 & 0.08 & 0.07 & 0.01 & 0.16 \\
\hline C14:0 & $11.55^{\mathrm{b}}$ & $11.63^{\mathrm{b}}$ & $12.52^{\mathrm{a}}$ & 0.45 & 0.03 \\
\hline C14:1 & 0.81 & 0.74 & 0.95 & 0.05 & 0.12 \\
\hline C15:0 & 0.98 & 0.99 & 0.97 & 0.02 & 0.72 \\
\hline C15:1 & 0.09 & 0.24 & 0.09 & 0.04 & 0.46 \\
\hline C16:0 & $37.11^{\mathrm{b}}$ & $40.88^{\mathrm{a}}$ & $40.64^{\mathrm{a}}$ & 1.24 & 0.02 \\
\hline C16:1 & 1.21 & 0.91 & 1.26 & 0.08 & 0.16 \\
\hline C17:0 & 0.31 & 0.45 & 0.40 & 0.05 & 0.56 \\
\hline C17:1 & 0.13 & 0.11 & 0.18 & 0.03 & 0.34 \\
\hline C18:0 & 8.98 & 8.31 & 7.55 & 0.39 & 0.44 \\
\hline C18:1 trans-10 & 0.52 & 0.01 & 0.01 & 0.16 & 0.40 \\
\hline C18:1 trans-11 & 0.68 & 0.02 & 0.02 & 0.21 & 0.41 \\
\hline C18:1n-9 cis & 21.10 & 18.35 & 18.88 & 1.10 & 0.21 \\
\hline $\mathrm{C} 18: 2 \mathrm{n}-6$ trans & 0.65 & 0.57 & 0.67 & 0.03 & 0.51 \\
\hline C18:2n-6 cis & 0.13 & 0.01 & 0.03 & 0.03 & 0.34 \\
\hline C20:0 & 0.12 & $\mathrm{ND}^{2}$ & 0.02 & 0.03 & 0.45 \\
\hline C20:1n-9 & 0.11 & ND & ND & 0.03 & 0.17 \\
\hline C18:3n-6 & 0.02 & ND & ND & 0.01 & 0.44 \\
\hline C18:3n-3 & 0.42 & 0.39 & 0.26 & 0.05 & 0.08 \\
\hline C18:2 cis-9,trans-11 & 0.63 & 0.49 & 0.49 & 0.06 & 0.42 \\
\hline $\mathrm{C} 20: 2$ & 0.20 & 0.01 & 0.06 & 0.06 & 0.45 \\
\hline C22:0 & ND & 0.19 & 0.12 & 0.06 & 0.29 \\
\hline C20:3n-3 & 0.02 & 0.09 & ND & 0.03 & 0.47 \\
\hline C20:3n-6 & 0.09 & 0.15 & 0.08 & 0.04 & 0.49 \\
\hline C22:1n-9 & 0.42 & 0.23 & 0.02 & 0.13 & 0.33 \\
\hline C23:0 & 0.01 & 0.38 & 0.03 & 0.09 & 0.25 \\
\hline C20:4n-6 & 0.11 & 0.12 & 0.11 & 0.05 & 0.93 \\
\hline C22:2 & ND & 0.28 & ND & 0.09 & 0.39 \\
\hline C24:0 & 0.02 & 0.36 & 0.10 & 0.10 & 0.31 \\
\hline C20:5n-3 & $0.08^{\mathrm{a}}$ & $0.03^{\mathrm{b}}$ & $0.07^{\mathrm{ab}}$ & 0.02 & 0.04 \\
\hline C24:1n-9 & 0.24 & 0.12 & 0.03 & 0.08 & 0.43 \\
\hline $\mathrm{C} 22: 6 \mathrm{n}-3$ & 0.05 & 0.01 & 0.05 & 0.01 & 0.25 \\
\hline$\Sigma \mathrm{SFA}$ & 72.28 & 77.12 & 76.76 & 1.64 & 0.09 \\
\hline$\Sigma$ MUFA & 25.32 & 20.72 & 21.43 & 1.42 & 0.11 \\
\hline$\Sigma$ PUFA & 2.40 & 2.16 & 1.81 & 0.29 & 0.19 \\
\hline$\Sigma \mathrm{n}-3$ & $0.58^{\mathrm{a}}$ & $0.52^{\mathrm{a}}$ & $0.37^{\mathrm{b}}$ & 0.08 & $<0.01$ \\
\hline$\Sigma \mathrm{n}-6$ & 1.00 & 0.85 & 0.88 & 0.08 & 0.22 \\
\hline$\Sigma \mathrm{n}-6 / \Sigma \mathrm{n}-3$ & 1.75 & 1.73 & 2.80 & 0.25 & 0.11 \\
\hline$\Sigma$ PUFA $/ \Sigma$ SFA & 0.03 & 0.03 & 0.02 & 0.01 & 0.44 \\
\hline Atherogenic index & $3.39^{\mathrm{b}}$ & $4.17^{\mathrm{a}}$ & $4.34^{\mathrm{a}}$ & 0.36 & 0.03 \\
\hline Thrombogenic index & $3.92^{\mathrm{b}}$ & $4.79^{\mathrm{a}}$ & $5.05^{\mathrm{a}}$ & 0.11 & 0.04 \\
\hline
\end{tabular}

$\overline{a, b}$ Means in the same row with different superscript letters are significantly different $(P<0.05)$.

${ }^{1} \mathrm{Control}=$ no forage brassica supplemented; Turnip = diet supplemented with $5 \mathrm{~kg}$ (DM basis) of forage turnip; Rape $=$ diet supplemented with $5 \mathrm{~kg}$ (DM basis) of forage rape.

${ }^{2}$ Not detected. 
Table 8. Scores of the attributes considered in the sensory evaluation of Chanco cheese

\begin{tabular}{lccccc}
\hline & \multicolumn{3}{c}{ Diet $^{1}$} & & \\
\cline { 2 - 4 } Attribute & Control & Turnip & Rape & SEM & P-value \\
\hline Homogeneity & 7.00 & 6.36 & 5.82 & 0.23 & 0.10 \\
Holes & 3.46 & 4.76 & 3.72 & 0.50 & 0.59 \\
General smell & 3.97 & 4.40 & 4.86 & 0.25 & 0.40 \\
Smell of mature cheese & 3.33 & 3.56 & 3.88 & 0.19 & 0.55 \\
Smell of milk & 3.50 & 3.93 & 3.68 & 0.12 & 0.39 \\
Salty & 5.46 & 5.42 & 6.68 & 0.33 & 0.22 \\
Acid & 3.12 & 3.72 & 3.33 & 0.22 & 0.60 \\
Bitter & 2.45 & 2.98 & 3.25 & 0.21 & 0.34 \\
Spiciness before swallowing & 2.86 & 3.32 & 3.22 & 0.14 & 0.46 \\
Spiciness after swallowing & 2.46 & 2.69 & 2.91 & 0.14 & 0.48 \\
General flavor & 5.33 & 4.98 & 5.67 & 0.17 & 0.25 \\
Mature cheese flavor & 3.67 & 3.61 & 4.43 & 0.17 & 0.07 \\
Astringency & 3.74 & 3.78 & 3.52 & 0.13 & 0.74 \\
Hardness & 4.56 & 4.55 & 3.81 & 0.19 & 0.19 \\
Granularity & 4.14 & 4.37 & 4.12 & 0.21 & 0.89 \\
Sound & 3.84 & 4.18 & 3.41 & 0.28 & 0.61 \\
Humidity & 3.90 & 3.71 & 4.29 & 0.16 & 0.36 \\
Adherence & 3.36 & 3.58 & 3.42 & 0.07 & 0.48 \\
\hline
\end{tabular}

${ }^{1}$ Control = no forage brassica supplemented; Turnip = diet supplemented with $5 \mathrm{~kg}$ (DM basis) of forage turnip; Rape $=$ diet supplemented with $5 \mathrm{~kg}$ (DM basis) of forage rape.

more bitter and had more holes, greater adherence, and greater intensity of acidity, milk odor, and spiciness before swallowing (Figure 1).

According to the results obtained from the PCA, we observed that cheeses from the turnip and rape treatments presented greater intensity of aroma and flavor, and characteristics of feeding brassicas were also reflected in sensations of bitterness, spiciness, and acidity (Fenwick et al., 1983). This could be explained by the fact that the secondary compounds that derive from the forages can be easily transferred to milk or cheese (Wiedenhoeft and Barton, 1995).

McSweeney (2004) noted that during ripening of cheese, several biochemical processes occur, such as glycolysis, lipolysis, and proteolysis, the processes that degrade lactose, lipids, and proteins, respectively. This gives rise to important changes in the texture and sensory characteristic of cheeses. The metabolism of lactose and the hydrolysis of fats are of critical importance in the cheese industry, because both processes result in aroma and flavor properties in cheeses. In contrast, proteolysis brings about changes in texture by breaking down the protein network (McSweeney, 2004).

Milk contains lipoprotein lipase, a powerful enzyme that participates in the hydrolysis of triglycerides (Fox et al., 2000). Chilliard et al. (2003) concluded that a cow diet rich in unsaturated fats resulted in the decreased lipolytic enzymes in milk, leading to a lower intensity in the taste of milk and fresh cheese, as in the control diet in our experiment. This is in agreement with Chen et al. (2004), who showed a softer texture of cheeses made from milk with a higher content of UFA.
Therefore, we can infer that in the mammary gland, physiological regulation occurs between FA and the synthesis of lipoprotein lipase (Chilliard et al., 2003).

Ricotta cheese was evaluated through an informal sensory panel. The Ricotta cheeses from the brassica treatments could be distinguished by their greater bitterness, spiciness, and acidity.

\section{CONCLUSIONS}

Feeding cows forage brassicas substantially modified the FA profile in plasma, increasing the percentage of SFA and decreasing UFA, including some n-3 and n- 6 fatty acids. The SFA, primarily SCFA and MCFA, were increased in milk from cows fed brassicas, whereas UFA, including C18:2 cis-9, trans-11 and fatty acids belonging to the $\mathrm{n}-3$ family, decreased. Additionally, the atherogenic and thrombogenic indices and n-6/n-3 ratio increased. Supplementation with brassicas resulted in an increased percentage of FA C14:0 and C16:0 in Chanco cheese and a decrease in C20:5n-3 in Ricotta cheese. Feeding forage brassicas did not significantly modify the sensory characteristics of the cheeses. However, principal components analysis showed that the turnip and rape diets produced a greater intensity of flavor, aroma, spiciness, bitterness, and acidity.

\section{ACKNOWLEDGMENTS}

This study was sponsored by research grants 11150538 and 1170400 from FONDECYT (Fondo Nacional de Desarrollo Científico y Tecnológico, Chile). 
A
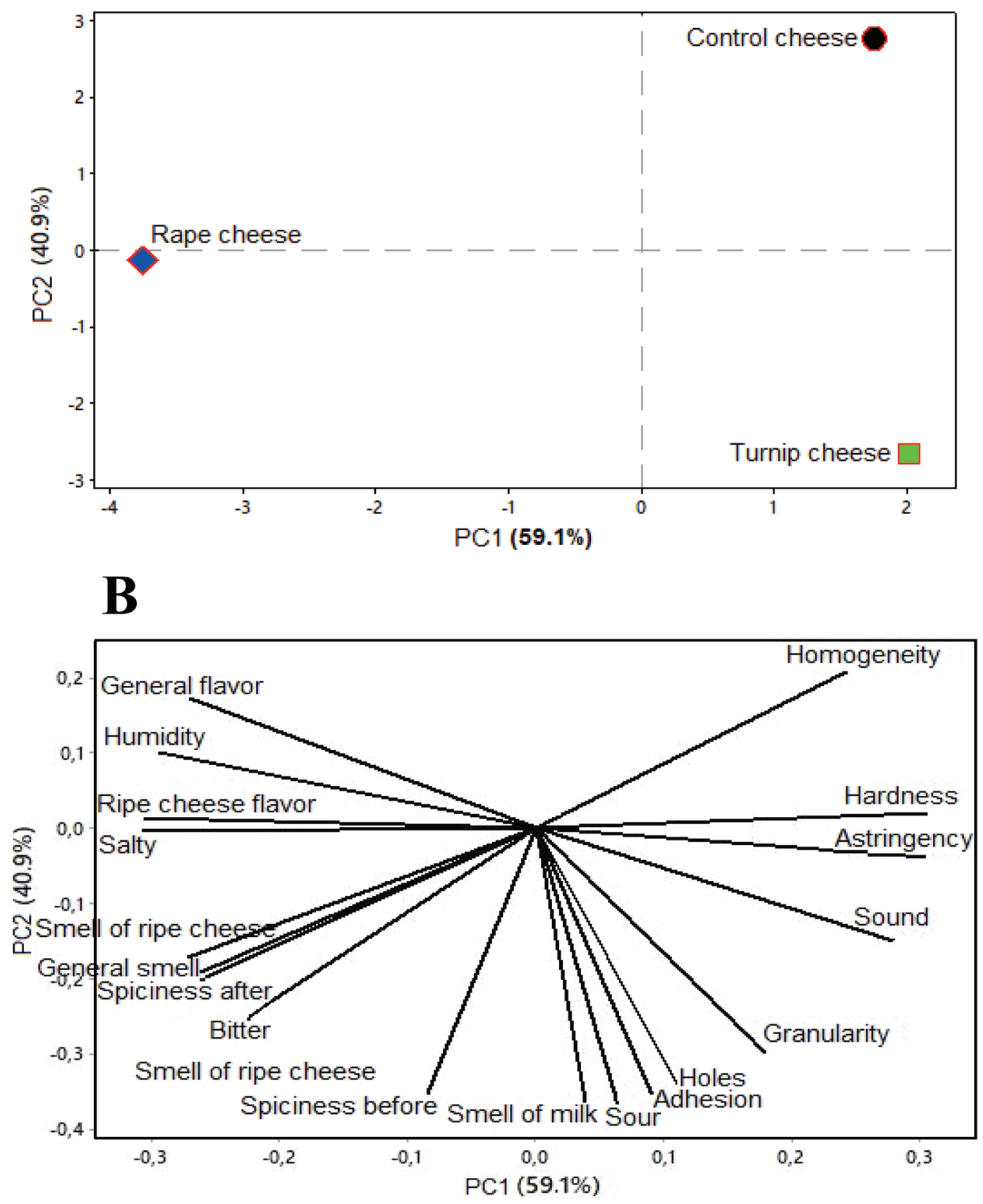

Figure 1. Principal components (PC) analysis for all 18 sensory attributes of all dietary treatments. Control $=$ no forage brassica supplemented; Turnip = diet supplemented with $5 \mathrm{~kg}$ of forage turnip; Rape = diet supplemented with $5 \mathrm{~kg}$ of forage rape (DM basis).

\section{REFERENCES}

Allred, S. L., T. R. Dhiman, C. P. Brennand, R. C. Khanal, D. J. McMahon, and N. D. Luchini. 2006. Milk and cheese from cows fed calcium salts of palm and fish oil alone or in combination with soybean products. J. Dairy Sci. 89:234-248.

AOAC International. 1996. Official Methods of Analysis. 16th ed. AOAC International, Gaithersburg, MD.
Barry, T. N. 2013. The feeding value of forage brassica plants for grazing ruminant livestock. Anim. Feed Sci. Technol. 181:15-25.

Bauman, D. E., M. A. McGuire, and K. J. Harvatine. 2011. Mammary gland, milk biosynthesis and secretion: Milk fat. Pages 352-358 in Encyclopedia of Dairy Sciences. 2nd ed. J. W. Fuquay, P. F. Fox, and P. L. H. McSweeney, ed. Academic Press, London, UK.

Bergamaschi, M., and G. Bittante. 2017. Detailed fatty acid profile of milk, cheese, ricotta and by products, from cows grazing summer highland pastures. J. Dairy Res. 84:329-338. 
Bligh, E. G., and W. J. Dyer. 1959. A rapid method of total lipid extraction and purification. Can. J. Biochem. Physiol. 37:911-917.

British Department of Health. 1994. Nutritional aspects of cardiovascular disease. Report of the Cardiovascular Review Group Committee on Medical Aspects of Food Policy. Rep. Health Soc. Subj. (Lond.) 46:1-186.

Cassida, K. A., K. E. Turner, J. G. Foster, and O. B. Hesterman. 2007. Comparison of detergent fiber analysis methods for forages high in pectin. Anim. Feed Sci. Technol. 135:283-295.

Chen, S., G. Bobe, S. Zimmerman, E. G. Hammond, C. M. Luhman, T. D. Boylston, A. E. Freeman, and D. C. Beitz. 2004. Physical and sensory properties of dairy products from cows with various milk fatty acid compositions. J. Agric. Food Chem. 52:3422-3428.

Chilliard, Y., A. Ferlay, and M. Doreau. 2001. Control of the nutritional quality of milk fat in the diets of dairy cows: Trans fatty acids, polyunsaturated, conjugated linoleic acid. Prod. Anim. 14:323-335.

Chilliard, Y., A. Ferlay, R. M. Mansbridge, and M. Doreau. 2000. Ruminant milk fat plasticity: nutritional control of saturated, polyunsaturated, trans and conjugated fatty acids. Ann. Zootech. 49:181-205.

Chilliard, Y., A. Ferlay, J. Rouel, and G. Lamberet. 2003. A review of nutritional and physiological factors affecting goat milk lipid synthesis and lipolysis. J. Dairy Sci. 86:1751-1770.

Chouinard, P. Y., L. Corneau, A. Saebo, and D. E. Bauman. 1999. Milk yield and composition during abomasal infusion of conjugated linoleic acids in dairy cows. J. Dairy Sci. 82:2737-2745.

Christie, W. W. 1982. A simple procedure for rapid transmethylation of glycerolipids and cholesteryl esters. J. Lipid Res. 23:1072-1075.

Clegg, R. A., M. C. Barber, L. Pooley, I. Ernens, Y. Larondelle, and M. T. Travers. 2001. Milk fat synthesis and secretion: Molecular and cellular aspects. Livest. Prod. Sci. 70:3-14.

Falchero, L., G. Lombardi, A. Gorlier, M. Lonati, M. Odoardi, and A. Cavallero. 2010. Variation in fatty acid composition of milk and cheese from cows grazed on two alpine pastures. Dairy Sci. Technol. 90:657-672.

Fenwick, G. R., R. Heaney, J. Mullin, and C. Vanetten. 1983. Glucosinolates and their breakdown products in food and food plants. Crit. Rev. Food Sci. Nutr. 18:123-201.

Fox, P. F., P. L. H. McSweeney, T. M. Cogan, and T. P. Guinee. 2000. Fundamentals of Cheese Science. Gaithersburg, MD. Springer US, New York, NY.

García, S. C., W. J. Fulkerson, and S. U. Brookes. 2008. Dry matter production, nutritive value and efficiency of nutrient utilization of a complementary forage rotation compared to a grass pasture system. Grass Forage Sci. 63:284-300.

Halmemies-Beauchet-Filleau, A., P. Kairenius, S. Ahvenjarvi, V. Toivonen, P. Huhtanen, A. Vanhatalo, D. I. Givens, and K. J. Shingfield. 2013. Effect of forage conservation method on plasma lipids, mammary lipogenesis, and milk fatty acid composition in lactating cows fed diets containing a 60:40 forage-to-concentrate ratio. J. Dairy Sci. 96:5267-5289.

Heid, H. W., and T. W. Keenan. 2005. Intracellular origin and secretion of milk fat globules. Eur. J. Cell Biol. 84:245-258.

Houston, M. 2018. The relationship of saturated fats and coronary heart disease: $\mathrm{Fa}(\mathrm{c}) \mathrm{t}$ or fiction? A commentary. Ther. Adv. Cardiovasc. Dis. 12:33-37.

Keim, J. P., I. F. Lopez, and O. A. Balocchi. 2015. Sward herbage accumulation and nutritive value as affected by pasture renovation strategy. Grass Forage Sci. 70:283-295.

Khan, M. M. H., and A. S. Chaudhry. 2011. A comparative study of low and high quality forages for chemical composition and in vitro degradability. J. Anim. Plant Sci. 21:715-723.

Lobos-Ortega, I., I. Revilla, M. I. Gonzalez-Martin, J. M. HernandezHierro, A. Vivar-Quintana, and C. Gonzalez-Perez. 2012. Conjugated linoleic acid contents in cheeses of different compositions during six months of ripening. Czech J. Food Sci. 30:220-226.

Lock, A. L., and P. C. Garnsworthy. 2002. Independent effects of dietary linoleic and linolenic fatty acids on the conjugated linoleic acid content of cows' milk. Anim. Sci. 74:163-176.
Lourenço, M., E. Ramos-Morales, and R. J. Wallace. 2010. The role of microbes in rumen lipolysis and biohydrogenation and their manipulation. Animal 4:1008-1023.

Maia, M. R., L. C. Chaudhary, C. S. Bestwick, A. J. Richardson, N. McKain, T. R. Larson, I. A. Graham, and R. J. Wallace. 2010. Toxicity of unsaturated fatty acids to the biohydrogenating ruminal bacterium, Butyrivibrio fibrisolvens. BMC Microbiol. 10:52.

Maia, M. R., L. C. Chaudhary, L. Figueres, and R. J. Wallace. 2007. Metabolism of polyunsaturated fatty acids and their toxicity to the microflora of the rumen. Antonie van Leeuwenhoek 91:303-314.

McIntosh, G., P. Roupas, and P. Royle. 2006. Cheese, omega-3 fatty acids, conjugated linoleic acid and human health. Aust. J. Dairy Technol. 61:142-146.

McSweeney, P. L. H. 2004. Biochemistry of cheese ripening. Int. J. Dairy Technol. 57:127-144.

Moate, P. J., D. E. Dalley, C. Grainger, A. Goudy, T. Clarke, P. Williams, and G. Limsowtin. 1996. The effect of feeding turnips on the concentration of thiocyanate in milk and consequences for cheese making. Aust. J. Dairy Technol. 51:1-5.

Moate, P. J., D. E. Dalley, K. Martin, and C. Grainger. 1998. Milk production responses to turnips fed to dairy cows in mid lactation. Aust. J. Exp. Agric. 38:117-123.

Nudda, A., M. A. McGuire, G. Battacone, and G. Pulina. 2005. Seasonal variation in conjugated linoleic acid and vaccenic acid in milk fat of sheep and its transfer to cheese and ricotta. J. Dairy Sci. 88:1311-1319.

O'Sullivan, T. A., K. Hafekost, F. Mitrou, and D. Lawrence. 2013. Food sources of saturated fat and the association with mortality: A meta-analysis. Am. J. Public Health 103:e31-e42.

Oliveira, M. N., and C. Brito. 2006. Brined cheeses and analogues of Latin American origin. Pages 211-248 in Brined Cheeses. A. Tamime, ed. Blackwell Publishing Ltd., Oxford, UK.

Pariza, M. W., Y. Park, and M. E. Cook. 2001. The biologically active isomers of conjugated linoleic acid. Prog. Lipid Res. 40:283-298.

Prieto, E., L. Mahecha, J. Angulo, and J. Vargas. 2016. Efecto de la suplementación lipídica sobre ácidos grasos en leche de vaca, énfasis en ácido ruménico. Agron. Mesoam. 27:421-437.

Pulido, R. G., R. Munoz, C. Jara, O. A. Balocchi, J. P. Smulders, F. Wittwer, P. Orellana, and M. O'Donovan. 2010. The effect of pasture allowance and concentrate supplementation type on milk production performance and dry matter intake of autumn-calving dairy cows in early lactation. Livest. Sci. 132:119-125.

Scerra, M., L. Chies, P. Caparra, C. Cilione, and F. Foti. 2016. Effect of only pasture on fatty acid composition of cow milk and ciminà caciocavallo cheese. J. Food Res. 5:20-28.

Schroeder, G. F., J. E. Delahoy, I. Vidaurreta, F. Bargo, G. A. Gagliostro, and L. D. Muller. 2003. Milk fatty acid composition of cows fed a total mixed ration or pasture plus concentrates replacing corn with fat. J. Dairy Sci. 86:3237-3248.

Shankaranarayana, M. L., B. Raghavan, K. O. Abraham, and P. C. Natarajan. 1974. Volatile sulphur compounds in food flavours. CRC Crit. Rev. Food Sci. Nutr. 4:395-435.

Sharafi, Y., M. M. Majidi, S. A. H. Goli, and F. Rashidi. 2015. Oil content and fatty acids composition in Brassica species. Int. J. Food Prop. 18:2145-2154.

Shingfield, K. J., S. Ahvenjarvi, V. Toivonen, A. Vanhatalo, P. Huhtanen, and J. M. Griinari. 2008. Effect of incremental levels of sunflower-seed oil in the diet on ruminal lipid metabolism in lactating cows. Br. J. Nutr. 99:971-983.

Sun, X. Z., D. Pacheco, and D. W. Luo. 2016. Forage brassica: A feed to mitigate enteric methane emissions? Anim. Prod. Sci. 56:451456.

Sun, X. Z., G. C. Waghorn, S. O. Hoskin, S. J. Harrison, S. Muetzel, and D. Pacheco. 2012. Methane emissions from sheep fed fresh brassicas (Brassica spp.) compared to perennial ryegrass (Lolium perenne). Anim. Feed Sci. Technol. 176:107-116.

Thomson, N., D. Clark, D. Waugh, W. Van Der Poel, and A. Macgibbon. 2000. Effect on milk characteristics to supplementing cows on a restricted pasture allowance with different amounts of either turnips or sorghum. Proc. N.Z. Soc. Anim. Prod. 60:320-323. 
Ulbricht, T. L., and D. A. Southgate. 1991. Coronary heart disease: Seven dietary factors. Lancet 338:985-992.

Van Soest, P. J., J. B. Robertson, and B. A. Lewis. 1991. Methods for dietary fibre, neutral detergent fibre and non-starch polysaccharides in relation to animal nutrition. J. Dairy Sci. 74:3583-3597.

Vargas-Bello-Pérez, E., K. Fehrmann-Cartes, G. Íñiguez-González, P. Toro-Mujica, and P. C. Garnsworthy. 2015. Chemical composition, fatty acid composition, and sensory characteristics of Chanco cheese from dairy cows supplemented with soybean and hydrogenated vegetable oils. J. Dairy Sci. 98:111-117.

Vargas-Bello-Pérez, E., C. Geldsetzer-Mendoza, M. S. Morales, P. Toro-Mujica, M. A. Fellenberg, R. A. Ibáñez, P. Gómez-Cortés, and P. C. Garnsworthy. 2018. Effect of olive oil in dairy cow diets on the fatty acid profile and sensory characteristics of cheese. Int. Dairy J. 85:8-15.
Vyhmeister, S., C. Geldsetzer-Mendoza, M. Medel-Marabolí, A. Fellenberg, E. Vargas-Bello-Pérez, and R. A. Ibáñez. 2019. Influence of using different proportions of cow and goat milk on the chemical, textural and sensory properties of Chanco-style cheese with equal composition. LWT 112:108226.

Wiedenhoeft, M. H., and B. A. Barton. 1995. Taste quality of milk from dairy cows fed forage brassica cv Tyfon. J. Sustain. Agric. 5:139-146.

\section{ORCIDS}

Juan Pablo Keim @ https://orcid.org/0000-0003-4277-6491

Einar Vargas-Bello-Pérez (0) https://orcid.org/0000-0001-7105-5752

Christian Alvarado-Gilis ำ https://orcid.org/0000-0002-7742-486X 